\title{
Continuous Long Term Simulations for Evaluating Storage-Treatment Design Options of Stormwater Filters
}

\section{Robert Pitt, John Voorhees and Shirley Clark}

Stormwater media filters are used to treat a variety of pollutants at different source areas. These can range from being simple rain gardens or biofilters containing soils or special media, to proprietary devices. Historically, sand filters and sand-peat filters were some of the earliest filters used for stormwater control. Austin (1988), Galli (1990), Shaver (1994), Claytor and Schuler (1996), and Urbonas (1999) all include descriptions and performance information for these fundamental stormwater filtration systems. These filters have been used to treat a variety of conventional stormwater pollutants, mostly focusing on suspended solids and nutrients.

Continued research has examined additional media and expanded our understanding of stormwater media filters. Clark and Pitt (1999) include an extensive review of different media, designs, and expected performance. Many proprietary stormwater filters are also now available and usually include cartridges of specialized media that can target specific classes of stormwater contaminants. Descriptions of many of these devices have been described at technical conferences, especially the annual StormCon conference (http://www.stormcon.com/) where vendors have extensive exhibits showcasing these filters. The International BMP Database has much data describing actual field performance for a wide range of stormwater filters (http://www.bmpdatabase.org/).

This chapter focuses on an important issue pertaining mostly to the proprietary filters that are sized to be within the guidelines of regulatory agencies. There is much confusion associated with sizing filter installations

Pitt, R.E., J. Voorhees and S. Clark. 2011. "Continuous Long Term Simulations for Evaluating Storage Treatment Design Options of Stormwater Filters." Journal of Water Management Modeling R241-07. doi: 10.14796/JWMM.R241-07.

(C) CHI 2011 www.chijournal.org ISSN: 2292-6062 (Formerly in Cognitive Modeling of Urban Water Systems. ISBN: 978-0-9808853-4-7) 
in order to meet a specific volume based criterion. As an example, regulatory agencies may require individual stormwater controls to treat at least a half inch of runoff. For sedimentation practices, this has usually been interpreted as the water quality treatment volume (such as the volume in a wet detention pond above the normal dry weather elevation and below the emergency spillway). For a filtering system, and other flow-through controls, stormwater treatment is more clearly associated with flow rates, not volumes.

Some agencies have therefore resorted to transforming the volume objective to a treatment flow rate, using a single design storm and an assumed hydrograph shape. This approach greatly decreases the flexibility in the design and does not adequately consider the interaction between storage and treatment flow rates. This chapter illustrates a simple method using continuous long term simulations that are much better suited in sizing and evaluating these flow-based treatment systems.

The long-term performance of a stormwater treatment filter is dependent on the amount of the annual runoff that is treated by the unit and by the level of treatment that is provided by the filter to the water passing through it. Most performance summaries assume that all of the runoff is treated, and therefore overestimate the level of treatment provided. Over a long period this is not a reasonable assumption, as the largest peak flows are substantially greater than flows that occur most of the time. Most filters usually have maximum treatment flow rates that can be utilized per filter unit (per unit area of filter surface, per filter module, or some other measure) to obtain the stated treatment level of the treated water. However, the use of up-gradient storage can moderate the high flows, decreasing the amount of stormwater that bypasses without treatment. The sizing of this adjacent storage should be done in conjunction with a continuous model that can evaluate many storage-treatment combinations.

This chapter presents a framework, through examples, for sizing stormwater treatment filters using long-term simulations. These simulations can be used to predict performance and to prepare design curves in order to size stormwater filters for specific areas.

The chapter starts with a discussion of the need for continuous long-term simulations for water quality stormwater controls, and then describes some basic aspects of urban hydrology that affect filter performance and design. The use of correctly conceived urban hydrologic processes is critical, especially when calculating flows associated with small and intermediate sized rains. These processes, in conjunction with long-term simulations, allow accurate estimates to be made. Probability distributions of modeling outcomes that relate to many receiving water objectives in urban areas can also be prepared from the results of long term water quality simulations. The use 
of single design storms and hydrological calculations that focus on larger events do not provide accurate information for the rains which affect receiving water resources and distort information pertaining to the sources of flows and pollutants.

Examples for several different treatment objectives are presented in this chapter for Madison, Wisconsin, using a 5 y rainfall record that was selected as being representative of long term conditions. These examples show how the treatment flow rate is dependent on treatment objectives, and how storage can be used in some cases to reduce the overall expected costs of the treatment systems. The framework presented in this chapter can be used by regulators to assist in the development of regulations pertaining to treatment goals for local conditions; by manufactures of stormwater filters in the preparation of design curves to assist in the sizing of filter units to meet these objectives; and by stormwater designers to help select alternative stormwater treatment systems.

\subsection{Continuous Long Term Simulation}

The need for continuous long term simulations for hydraulic designs has been recognized and strongly encouraged for many years, especially when considering water quality regulatory issues and receiving water impacts. However, many designers and regulators persist in using single event design storms. This approach may work adequately for many drainage system designs, but is not suitable for water quality analyses where the most problematic storm conditions are not obvious.

Gregory and James (1995) provide a comprehensive review of the need for continuous simulations and discuss the usual attributes concerning their use. They state that long term continuous modeling is essential for simulating the long term impacts of urban drainage systems on aquatic ecosystems. They conclude that managing time series data for three human generations, or 75 years, is a critical task requiring specialized data management systems. Using this time period is feasible with the availability of accessible rainfall data, but continuous data with no missing periods may be difficult to obtain. It is usually possible to process the available rainfall data to obtain shorter periods of representative data. These shorter periods still should include as many years as possible. Donigan and Linsley (1979) state that continuous models simulate hydrological processes during both wet and dry weather periods, thus avoiding the problem of specifying arbitrary antecedent conditions that are needed for single event models. They further state that only continuous simulations can provide the necessary information to evaluate the probability of the occurrence of undesirable water quality conditions. 
Pitt and Clark (2008) review additional issues associated with the need for continuous simulations for stormwater quality evaluations. They stress that different drainage design criteria and receiving water use objectives often require the examination of different types of rains for the design of urban drainage systems. These different (and often conflicting) objectives of a stormwater drainage system can be addressed by examining distinct portions of the long term rainfall record.

Most of the urban hydrology methods currently used for drainage design have been successfully used for large design storms. This approach (providing urban areas safe from excessive flooding and associated flood related damages) is the most critical objective of urban drainage. However, it is now possible (and legally required) to provide urban drainage systems that also minimize other problems associated with urban stormwater. This broader set of urban drainage objectives requires a broader approach to drainage design, and the use of hydrology methods with different assumptions and simplifications.

In this chapter, WinSLAMM, the source loading and management model, is used to conduct long-term simulations of a simple impervious area, indicating how stormwater filters can be sized, including additional storage, to meet specific water quality treatment objectives. The major features of WinSLAMM, including how urban hydrology is modeled in the program, have been described in past monographs associated with this conference series, and elsewhere (Pitt 1986; 1987; 1997; 1999; Pitt and Voorhees 1995; 2007).

\subsection{Filter Flow Rate Analyses}

The following is a detailed analysis of treatment flow rates for Madison using a $5 \mathrm{y}$ rain period that has been determined by the U.S. Geological Survey (USGS) to be representative of long term conditions (1980 through 1984). There were no unusual rains during this period, with the largest rains that occurred each year being about 3 in. $(76 \mathrm{~mm})$ in depth. These analyses do not consider winter events (Oct 15 of each year through Feb 15 of the following year). Snowmelt can also affect filter designs, but that discussion is beyond the scope of this chapter. The calculations also show how combinations of storage and treatment can be used to optimize the design of a filtration system.

A 1 acre $(0.4 \mathrm{ha})$ commercial paved parking area was modeled as an example of where a stormwater media filter would be used. The results can be extrapolated to differently sized impervious areas in the south central Wisconsin area. Calibrated regional model parameter files (available from the 
Wisconsin USGS website, http://wi.water.usgs.gov/slamm/inde7.html) were used. The output option for detailed 6 min hydrograph time steps was selected.

The storage volume effects on the flow distribution were determined by using storage tanks, and then using flow control orifices with different diameters. This is a simplified analysis and the use of other upgradient storage configurations would have a similar effect. The maximum depth in the storage tanks during the $5 \mathrm{y}$ continuous simulation was therefore used to determine the maximum storage volume needed.

Flow control orifices with diameters from $0.1 \mathrm{ft}$ to $2 \mathrm{ft}(31 \mathrm{~mm}$ to 610 $\mathrm{mm}$ ) were examined for each scenario. The storage tanks used for the large diameter orifices were $7.5 \mathrm{ft}(2.2 \mathrm{~m})$ diameter, and the maximum water depths were approximately $5 \mathrm{ft}(1.5 \mathrm{~m})$, as shown in Table 7.1. The $1 \mathrm{ft}$ (31 $\mathrm{cm})$ and $2 \mathrm{ft}(61 \mathrm{~cm})$ diameter orifices in these tanks resulted in $<1 \mathrm{ft}(31$ $\mathrm{cm})$ depth, and therefore relatively small storage requirements. As shown later, these diameter orifices also provide little peak flow rate attenuation, as expected. For the smaller diameter orifices, the tank areas were increased by a factor of 10, resulting in tanks of approximately $10 \mathrm{ft}$ x $45 \mathrm{ft}(3.1 \mathrm{~m} \mathrm{x} 13.7$ $\mathrm{m})$ area. The resulting water depths in the tanks with these smaller diameter orifices ranged from approximately $3 \mathrm{ft}$ to $13 \mathrm{ft}(0.9 \mathrm{~m}$ to $4 \mathrm{~m})$, with resulting significant storage volumes over the drainage area.

Table 7.1 Storage tanks and orifices used affecting the long term flow distributions.

\begin{tabular}{cccccc}
\hline $\begin{array}{c}\text { Orifice diameter } \\
(\mathrm{ft})\end{array}$ & $\begin{array}{c}\text { Peak flow } \\
\text { expected } \\
\left(\mathrm{ft}^{3} / \mathrm{s} / \text { acre }\right)\end{array}$ & $\begin{array}{c}\text { Peak flow } \\
\text { expected } \\
(\mathrm{gal} / \mathrm{min} / \text { acre })\end{array}$ & $\begin{array}{c}\text { Maximum stor- } \\
\text { age depth above } \\
\text { orifice }(\mathrm{ft})\end{array}$ & $\begin{array}{c}\text { Total stor- } \\
\text { age }\left(\mathrm{ft}^{3}\right)\end{array}$ & $\begin{array}{c}\text { Storage (in. } \\
\text { over water- } \\
\text { shed surface) }\end{array}$ \\
\hline no storage & 2.26 & 1020 & 0 & 0 & 0.0000 \\
2 & 2.27 & 1020 & 0.055 & 2 & 0.0007 \\
1 & 1.82 & 818 & 0.81 & 35 & 0.010 \\
0.5 & 1.55 & 696 & 5.22 & 228 & 0.063 \\
0.375 & 0.86 & 387 & 2.84 & 1240 & 0.34 \\
0.25 & 0.54 & 241 & 5.30 & 2310 & 0.64 \\
0.15 & 0.25 & 113 & 8.90 & 3880 & 1.1 \\
0.10 & 0.13 & 60 & 12.5 & 5430 & 1.5 \\
\hline
\end{tabular}

As an example, Table 7.1 shows that the $0.25 \mathrm{ft}(76 \mathrm{~mm})$ diameter orifice would require a $10 \mathrm{ft} \times 45 \mathrm{ft}(3.1 \mathrm{~m} \times 13.7 \mathrm{~m})$ tank with a depth of $5.3 \mathrm{ft}(1.6$ $\mathrm{m})$ for 1 acre $(0.41 \mathrm{ha})$ impervious area, resulting in a storage depth of approximately $0.64 \mathrm{in}$. $(16 \mathrm{~mm})$ over the drainage area $(0.053$ acre-ft/acre paved area). The peak flow rate for the paved area would be reduced from about $1020 \mathrm{gal} / \mathrm{min}(64 \mathrm{~L} / \mathrm{s})$ with no storage, to $240 \mathrm{gal} / \mathrm{min}(15 \mathrm{~L} / \mathrm{s})$ with this amount of storage and flow control. 
Figure 7.1 is a plot of the resulting peak flow rates expected for different amounts of storage from the 1 acre $(0.4 \mathrm{ha})$ paved area. As an example, this figure shows that 0.25 acre-in. $\left(26 \mathrm{~m}^{3}\right)$ storage would be needed to reduce the peak flow by half, compared to no storage.



Figure 7.1 Effects of storage on peak flow rates.

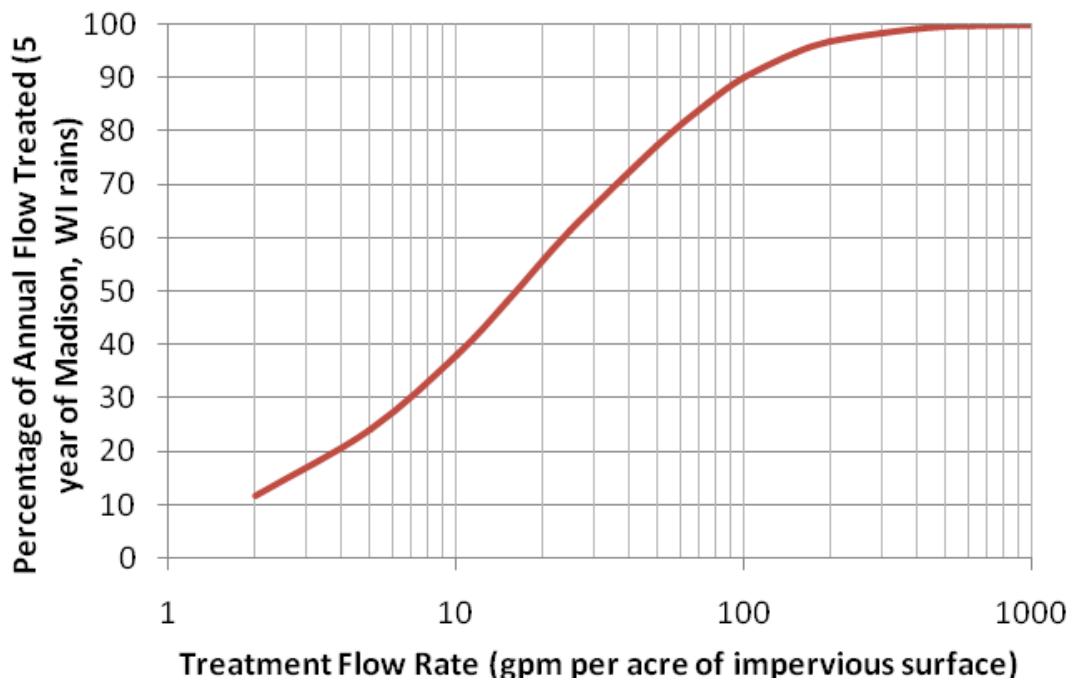

Figure 7.2 Percentage of annual flows treated for different treatment flow rates (no storage). 
Figure 7.2 is a plot of the percentage of the annual flows treated for different treatment flow rates. If the actual flows entering a treatment filter exceed the treatment flow capacity of the filter, flows will bypass the treatment. However, the portion of the flow that is equal to the treatment flow rate will still be treated. Therefore, continuous modeling was used to examine the 6 min flow increments entering the filter. If this flow was less than the treatment flow rate, all of the flow was assumed to be treated. For flows in excess of the treatment flow rate, the portion that bypasses the filter is not treated. As an example, treatment of $90 \%$ of the total period runoff would require a treatment flow rate of about $100 \mathrm{gal} / \mathrm{min}(6.3 \mathrm{~L} / \mathrm{s})$ for each acre ( $0.4 \mathrm{ha})$ of pavement. The treatment flow rates needed to treat $100 \%$ of the total flows are much greater (by a factor of about 5). Obviously, treating this last $10 \%$ of the annual flow does not make much sense economically, as the funds would likely be better used to treat almost all (but not all) of the runoff from a much larger area.

The use of storage before the media filters reduces the required treatment flow rates to provide the same level of control of annual runoff volumes. Accordingly, the treatment flow rate analysis was repeated to quantify the benefits of different runoff storage volumes. Calculations were performed in the same manner as those described above, except that small storage tanks and controlled orifice outlets were used before the 6 min flow rates were calculated. The results are shown in Figure 7.3.

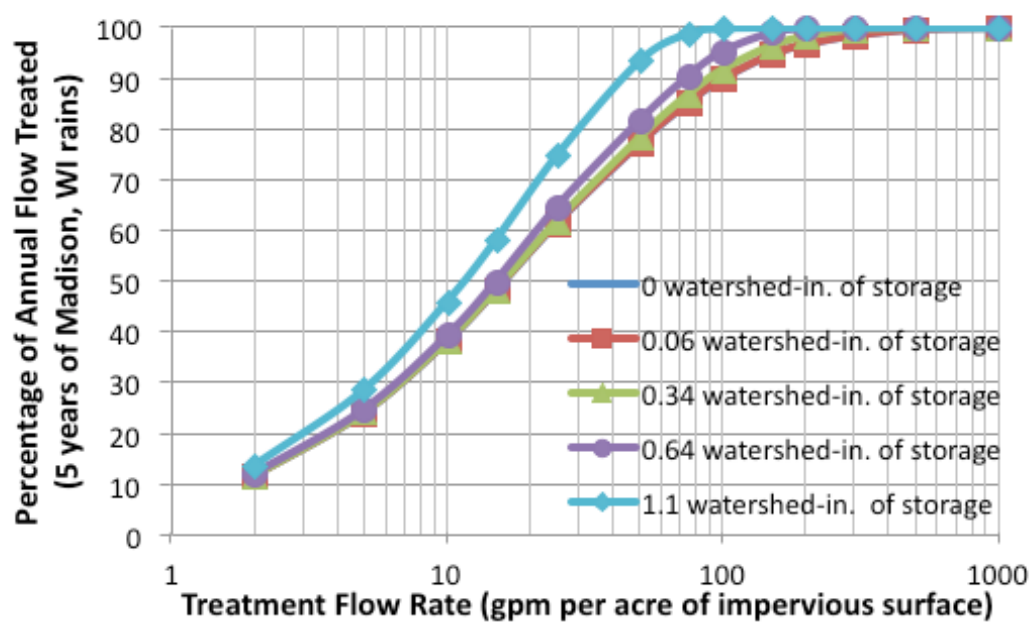

Figure 7.3 Effects of treatment flow rate and storage on percentage of annual flow treated, 1980 through 1985, Madison rains and 1 acre commercial paved parking area. 
This figure indicates that the largest amounts of storage had large effects on the needed treatment flow rates, as expected. As an example, for $90 \%$ of the annual total flows to be treated, a treatment flow rate of $100 \mathrm{gal} / \mathrm{min} / \mathrm{acre}$ $(16 \mathrm{~L} / \mathrm{s} / \mathrm{ha})$ is needed when no storage, or the smallest amount of storage, 0.06 acre-in. $\left(6.5 \mathrm{~m}^{3}\right)$, is used. When the storage is increased to 0.34 acre-in. $\left(35 \mathrm{~m}^{3}\right)$ the treatment flow rate is only slightly reduced to $90 \mathrm{gal} / \mathrm{min} /$ acre (14 L/s/ha).

When the storage is increased to 0.64 acre-in. $\left(66 \mathrm{~m}^{3}\right)$ the treatment flow rate is reduced to $65 \mathrm{gal} / \mathrm{min} /$ acre $(10 \mathrm{~L} / \mathrm{s} / \mathrm{ha})$, and when the storage is further increased to the maximum shown, 1.1 acre-in. $\left(110 \mathrm{~m}^{3}\right)$, the treatment flow rate is further reduced to $45 \mathrm{gal} / \mathrm{min} / \mathrm{acre}(7.0 \mathrm{~L} / \mathrm{s} / \mathrm{ha})$ for the $90 \%$ treatment goal.

Since this figure is based on a unit area of pavement (where these devices are most likely to be used), these plots can be applied for the whole region where the rain file is used. As an example, the Wisconsin Department of Natural Resources and the USGS have created five regions in Wisconsin with different rain files (including ones in Duluth and Minneapolis for areas of Wisconsin close to these out-of-state areas).

Figure 7.4 plots the interaction of the treatment flow rates and watershed storage volumes in order to treat $80 \%, 90 \%$ and $95 \%$ of the annual total runoff from impervious surfaces (likely candidate goals for an area).

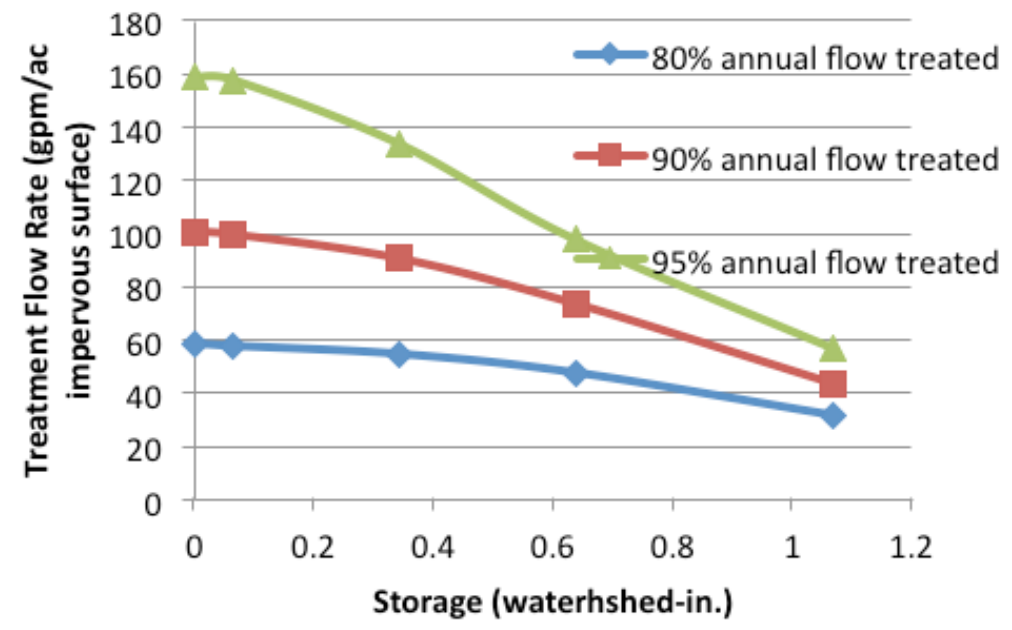

Figure 7.4 Treatment flow rates and storage requirements for annual runoff treatment goals.

The overall pollutant reduction would of course depend on how well the treatment system reduced the contaminants in the water passing through the 
device, which would likely vary with time due to flow rates and maintenance issues. As Urbonas (1999) illustrated, many stormwater filter installations clog much earlier than expected due to poor maintenance, with the resultant bypassing of much larger fractions of flows than assumed. Therefore, these flow analyses must be supported by filter performance data reflecting actual maintenance and other data. A regulatory agency may correspondingly require a greater treatment flow capacity than indicated by these analyses.

It is therefore neither difficult nor time consuming to create these plots using long term rain records that can then support the sizing of flow-through treatment systems that would treat the desired portion of the annual flows. As noted above, the most suitable combination of storage and treatment flow rate for a specific site is dependent on many considerations.

The following section presents economic analyses illustrating different treatment objectives and different combinations of storage volumes and filtration flow rates as an illustration of how a design engineer can select the most cost-effective filtration system for a site.

\subsection{Evaluations of Storage-Treatment Options}

There are many combinations of storage and treatment that can be used to meet a specific treatment goal. The following discussion presents some simple examples showing traditional storage-treatment analyses using assumed costs for the separate filtration and storage components.

Examples are given for specific fractions of the total runoff volume to be treated, and for treatment level goals that may be provided by TMDL (total maximum daily load) based regulations.

\subsubsection{Hypothetical Filter Costs}

The following is a hypothetical evaluation loosely based on actual products and costs. Due to the nature of this chapter, references to specific products are neither needed nor desired. A typical cartridge stormwater filter is assumed, along with prefabricated storage vaults.

In this example, a vault contains multiple filter units. The basic vault has some inherent storage upgradient from the filters, and additional storage can be added. Each of the basic units is a vault containing multiple cartridges that can each treat $7.5 \mathrm{gal} / \mathrm{min}(0.47 \mathrm{~L} / \mathrm{s})$. Two different filter arrangements are examined in these examples: a large filter vault that can contain up to 15 cartridges ( 3 rows of 5 each) that has an area of $8 \mathrm{ft} \times 15 \mathrm{ft}(2.4 \mathrm{~m} \mathrm{x} 4.6 \mathrm{~m})$; and a smaller vault that can hold 6 cartridges and has an area of $8 \mathrm{ft} \times 4 \mathrm{ft}$ $(2.4 \mathrm{~m} \mathrm{x} 1.2 \mathrm{~m})$. As noted, each vault also has some inherent storage before 
the filter cartridges: $360 \mathrm{ft}^{3}\left(10 \mathrm{~m}^{3}\right)$ for the large vault and $72 \mathrm{ft}^{3}\left(2.0 \mathrm{~m}^{3}\right)$ for the small vault.

The basic small vault (with filters) is estimated to cost $\$ 10000$, and the basic large vault (with filters) is estimated to cost $\$ 20000$. Each additional filter cartridge costs $\$ 1500$. You can increase the treatment flow rate by adding additional filter vault units for the area, or using a larger vault able to contain more cartridges (which is not considered in these examples). Table 7.2 summarizes the basic options for different treatment flow rate objectives.

Table 7.2 Hypothetical costs for stormwater filters.

\begin{tabular}{lccc}
\hline & $\begin{array}{c}\text { \$ Cost for filters } \\
\text { and basic vault }\end{array}$ & $\begin{array}{c}\text { Total treatment } \\
\text { flow rate }(\mathrm{gpm})\end{array}$ & $\begin{array}{c}\text { Total storage in } \\
\text { basic unit }\left(\mathrm{ft}^{3}\right)\end{array}$ \\
\hline Small vault with 3 filter cartridges & 14500 & 22.5 & 72 \\
Small vault with 6 filter cartridges & 19000 & 45 & 72 \\
Large vault with 9 filter cartridges & 33500 & 67.5 & 360 \\
Large vault with 12 filter cartridges & 38000 & 90 & 360 \\
Large vault with 15 filter cartridges & 42500 & 112.5 & 360 \\
\hline
\end{tabular}

\subsubsection{Storage Volumes and Costs}

Additional storage can be added upgradient of the filters to reduce the needed treatment flow rates, based on the modeling shown in the first part of this chapter. The cost of this storage is estimated to be $\$ 5000$ for $200 \mathrm{ft}^{3}(5.7$ $\left.\mathrm{m}^{3}\right), \$ 15000$ for $1000 \mathrm{ft}^{3}\left(28 \mathrm{~m}^{3}\right)$, and $\$ 40000$ for $6000 \mathrm{ft}^{3}\left(85 \mathrm{~m}^{3}\right)$. Combinations of these storage units can be used for larger volumes. Table 7.3 summarizes these costs for the different storage volume options.

Table 7.3 Hypothetical costs for stormwater storage vaults.

\begin{tabular}{ccc}
\hline Total storage volume $\left(\mathrm{ft}^{3}\right)$ & $\begin{array}{c}\text { Number of each type of storage } \\
\text { tank }\left(200 \mathrm{ft}^{3}-1000 \mathrm{ft}^{3}-6000 \mathrm{ft}^{3}\right)\end{array}$ & Total cost for storage vaults (\$) \\
\hline 200 & $1-0-0$ & 5000 \\
400 & $2-0-0$ & 10000 \\
1000 & $0-1-0$ & 15000 \\
2000 & $0-2-0$ & 30000 \\
6000 & $0-0-1$ & 40000 \\
12000 & $0-0-2$ & 80000 \\
\hline
\end{tabular}

\subsubsection{Treating $90 \%$ of the Annual Runoff}

As shown in Table 7.4 and Figure 7.5, the most cost-effective solution is to use the basic filter only option with 15 filter cartridges at a total estimated cost of $\$ 42500 /$ acre ( $\$ 105000 /$ ha) impervious area (design option 1), without any additional storage. The storage can significantly reduce the filter treatment flow rate and filter costs, but the added cost is not offset by the reduced filter cost. 
Table 7.4 Treatment flow options to treat $90 \%$ annual runoff volume.

\begin{tabular}{ccccccc}
\hline $\begin{array}{c}\text { Design } \\
\text { option }\end{array}$ & $\begin{array}{c}\text { Storage } \\
\text { (acre- } \\
\text { inches) }\end{array}$ & $\begin{array}{c}\text { Storage } \\
\text { volume } \\
\left(\mathrm{ft}^{3} / \text { acre }\right)\end{array}$ & $\begin{array}{c}\text { Treatment } \\
\text { flow rate } \\
\text { needed } \\
(\mathrm{gal} / \mathrm{min} / \text { acre })\end{array}$ & $\begin{array}{c}\text { Cost for } \\
\text { filters }(\$)\end{array}$ & $\begin{array}{c}\text { Cost for } \\
\text { additional } \\
\text { storage }(\$)\end{array}$ & $\begin{array}{c}\text { Total } \\
\text { costs }(\$)\end{array}$ \\
\hline 1 & 0 & 0 & 100 & 42500 & $0^{*}$ & 42500 \\
2 & 0.063 & 228 & 100 & 42500 & $0 *$ & 42500 \\
3 & 0.34 & 1240 & 90 & 38000 & 15000 & 53000 \\
4 & 0.64 & 2310 & 65 & 33500 & 30000 & 63500 \\
5 & 1.1 & 3880 & 45 & 19000 & 40000 & 59000 \\
\hline
\end{tabular}

* There is no additional storage needed beyond the storage provided by the basic vault that contains the filter units.

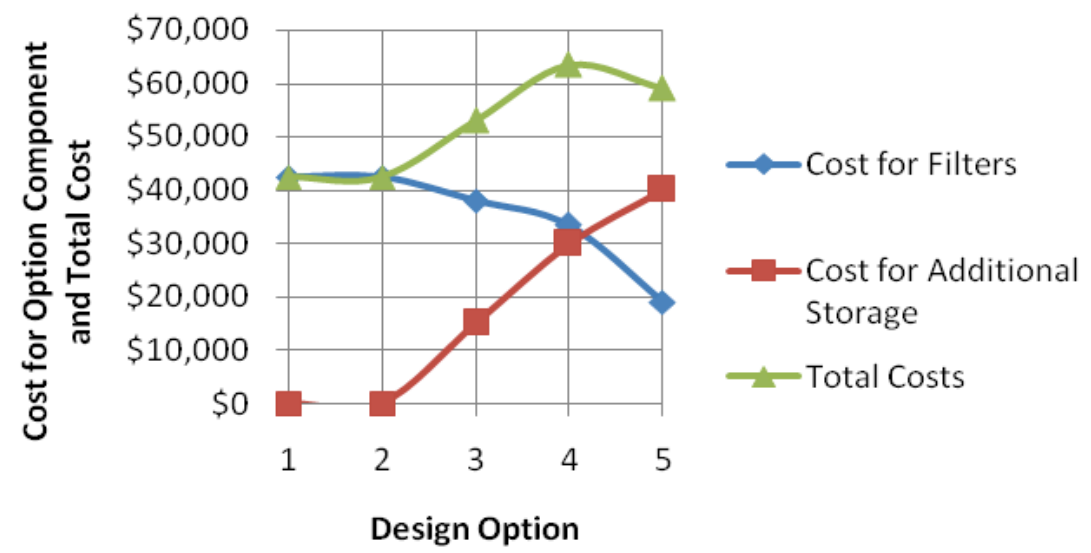

Figure 7.5 Costs for different storage-treatment options for $90 \%$ of annual flow control.

\subsubsection{Treating $100 \%$ of the Annual Runoff}

As shown in Table 7.5 and Figure 7.6, the most cost-effective solution when needing to treat $100 \%$ of the total annual flow is to use the largest amount of storage (design option 5), for a total estimated cost of $\$ 82500 /$ acre ( 0.4 ha) impervious area. Because of the large treatment flow rates, a more costeffective solution for this filter may be to use a larger vault that can contain the total number of filter cartridges in a single vault unit, as 70 cartridges are needed to treat the $500 \mathrm{gal} / \mathrm{min}(32 \mathrm{~L} / \mathrm{s})$ peak flow rate. The single much larger vault may cost less than the multiple units assumed in this example.

The increased cost to treat $100 \%$ of the peak expected flows is about twice the cost of treating $90 \%$ of the total runoff volume. It is likely that it would be much more cost effective to treat additional areas at a reduced cost than to treat smaller areas at a higher level of treatment. 
Table 7.5 Treatment flow options to treat $100 \%$ annual runoff volume.

\begin{tabular}{ccccccc}
\hline $\begin{array}{c}\text { Design } \\
\text { option }\end{array}$ & $\begin{array}{c}\text { Storage } \\
(\text { acre-in. })\end{array}$ & $\begin{array}{c}\text { Storage } \\
\text { volume } \\
\left(\mathrm{ft}^{3} / \mathrm{acre}\right)\end{array}$ & $\begin{array}{c}\text { Treatment flow } \\
\text { rate needed } \\
(\mathrm{gal} / \mathrm{min} / \mathrm{acre})\end{array}$ & $\begin{array}{c}\text { Cost for } \\
\text { filters } \\
(\$)\end{array}$ & $\begin{array}{c}\text { Cost for } \\
\text { additional } \\
\text { storage }(\$)\end{array}$ & $\begin{array}{c}\text { Total Cost } \\
(\$)\end{array}$ \\
\hline 1 & 0 & 0 & 500 & 212500 & 0 & 212500 \\
2 & 0.0627 & 228 & 500 & 212500 & 0 & 212500 \\
3 & 0.341 & 1240 & 300 & 127500 & 5000 & 132500 \\
4 & 0.636 & 2310 & 200 & 85000 & 30000 & 115000 \\
5 & 1.067 & 3880 & 100 & 42500 & 40000 & 82500 \\
\hline
\end{tabular}

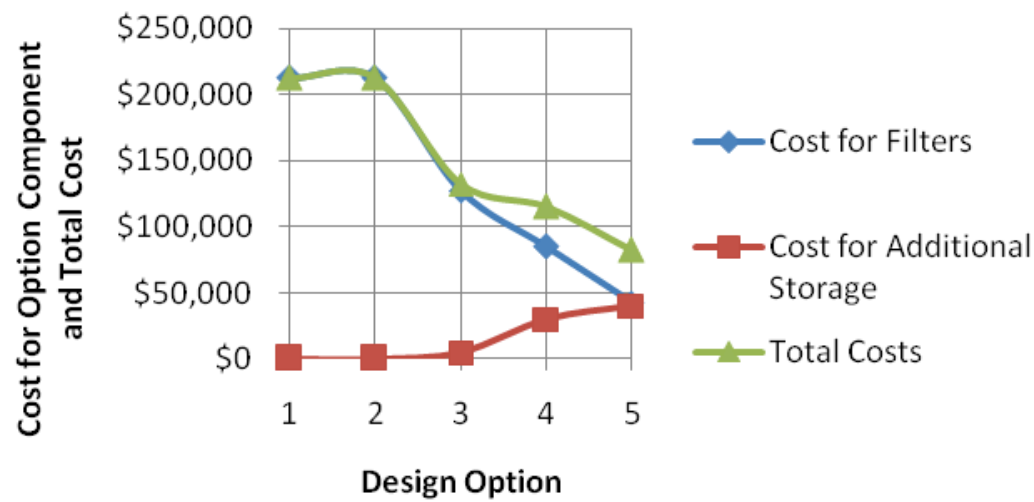

Figure 7.6 Costs for different storage-treatment options for $100 \%$ of annual flow control.

\subsubsection{Treating the Annual Runoff to Meet TMDL Requirements}

In this example, it is assumed that the filter unit can reduce the SSC at the $85 \%$ level under all flow conditions considered. This is a simplistic assumption used for these calculations. The treatment flow options vary for each level of control desired, as shown in Tables 7.6 and 7.7.

Table 7.6 Fraction of annual flows to be treated to meet load reduction goals.

\begin{tabular}{cc}
\hline Design option (\% SSC load reductions) & Fraction of total annual flow that must be treated \\
\hline 40 & $48 \%$ \\
60 & $71 \%$ \\
80 & $95 \%$ \\
\hline
\end{tabular}

As shown in Table 7.7 and Figure 7.7, only the smallest vault with two cartridges is needed to provide $40 \%$ reductions in SSC for any of these filter treatment rates. No additional storage is needed. The expected total cost is $\$ 13000 /$ acre (\$33 500/ha) of impervious area to meet this TMDL discharge goal. 
Table $7.740 \%$ SSC load reductions ( $48 \%$ annual flow treated at $85 \%$ reductions).

\begin{tabular}{ccccccc}
\hline $\begin{array}{c}\text { Design } \\
\text { option }\end{array}$ & $\begin{array}{c}\text { Storage } \\
(\text { acre-in. })\end{array}$ & $\begin{array}{c}\text { Storage } \\
\text { volume } \\
\left(\mathrm{ft}^{3} / \text { acre }\right)\end{array}$ & $\begin{array}{c}\text { Treatment } \\
\text { flow rate } \\
\text { needed } \\
(\mathrm{gal} / \mathrm{min} / \text { acre })\end{array}$ & $\begin{array}{c}\text { Cost for } \\
\text { filters }(\$)\end{array}$ & $\begin{array}{c}\text { Cost for } \\
\text { additional } \\
\text { storage }(\$)\end{array}$ & $\begin{array}{c}\text { Total costs } \\
(\$)\end{array}$ \\
\hline 1 & 0 & 0 & 14 & 13000 & 0 & 13000 \\
2 & 0.063 & 228 & 14 & 13000 & 0 & 13000 \\
3 & 0.34 & 1240 & 14 & 13000 & 5000 & 18000 \\
4 & 0.64 & 2310 & 13 & 13000 & 30000 & 43000 \\
5 & 1.1 & 3880 & 11 & 13000 & 40000 & 53000 \\
\hline
\end{tabular}
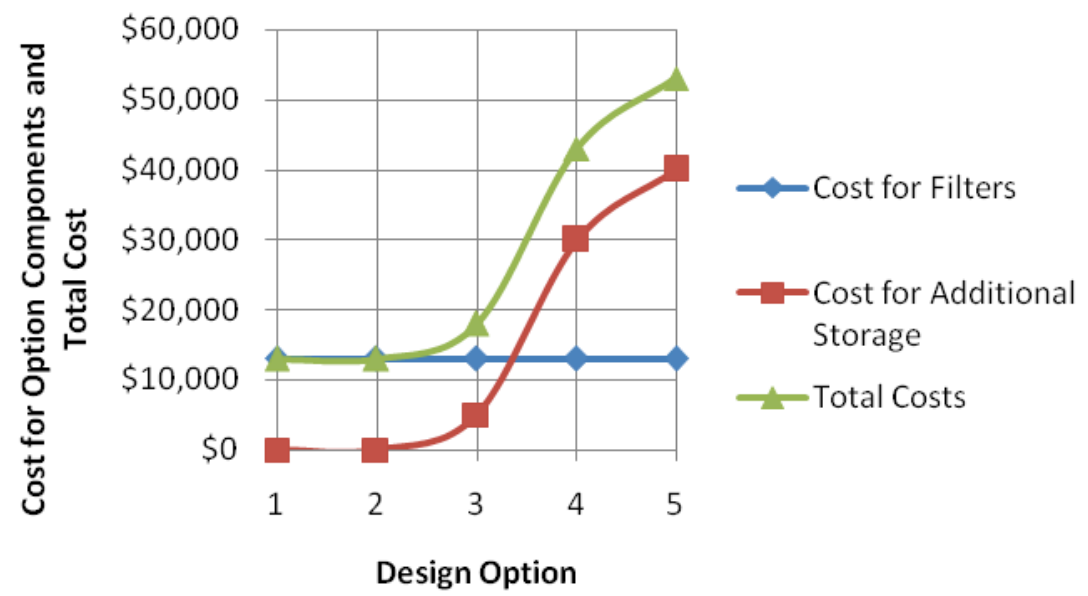

Figure 7.7 Costs for different storage-treatment options for $40 \%$ SSC load reductions.

Only the smallest vault with five filter cartridges is needed to provide the least cost option (shown in Table 7.8 and Figure 7.8) for an annual 60\% SSC yield reduction. The expected total cost is $\$ 19$ 000/acre ( $\$ 47000 /$ ha) of impervious area to meet this TMDL discharge goal.

Table $7.860 \%$ SSC load reductions ( $71 \%$ annual flow treated at $85 \%$ reductions).

\begin{tabular}{ccccccc}
\hline $\begin{array}{c}\text { Design } \\
\text { option }\end{array}$ & $\begin{array}{c}\text { Storage } \\
(\text { acre-in.) }\end{array}$ & $\begin{array}{c}\text { Storage } \\
\text { volume } \\
\left(\mathrm{ft}^{3} / \text { acre }\right)\end{array}$ & $\begin{array}{c}\text { Treatment flow } \\
\text { rate needed } \\
(\mathrm{gal} / \mathrm{min} / \text { acre })\end{array}$ & $\begin{array}{c}\text { Cost for } \\
\text { filters }(\$)\end{array}$ & $\begin{array}{c}\text { Cost for } \\
\text { additional } \\
\text { storage }(\$)\end{array}$ & $\begin{array}{c}\text { Total costs } \\
(\$)\end{array}$ \\
\hline 1 & 0 & 0 & 39 & 19000 & 0 & 19000 \\
2 & 0.0627 & 228 & 39 & 19000 & 0 & 19000 \\
3 & 0.341 & 1240 & 35 & 17500 & 5000 & 22500 \\
4 & 0.636 & 2310 & 32 & 17500 & 30000 & 47500 \\
5 & 1.067 & 3880 & 22 & 14500 & 40000 & 54500 \\
\hline
\end{tabular}




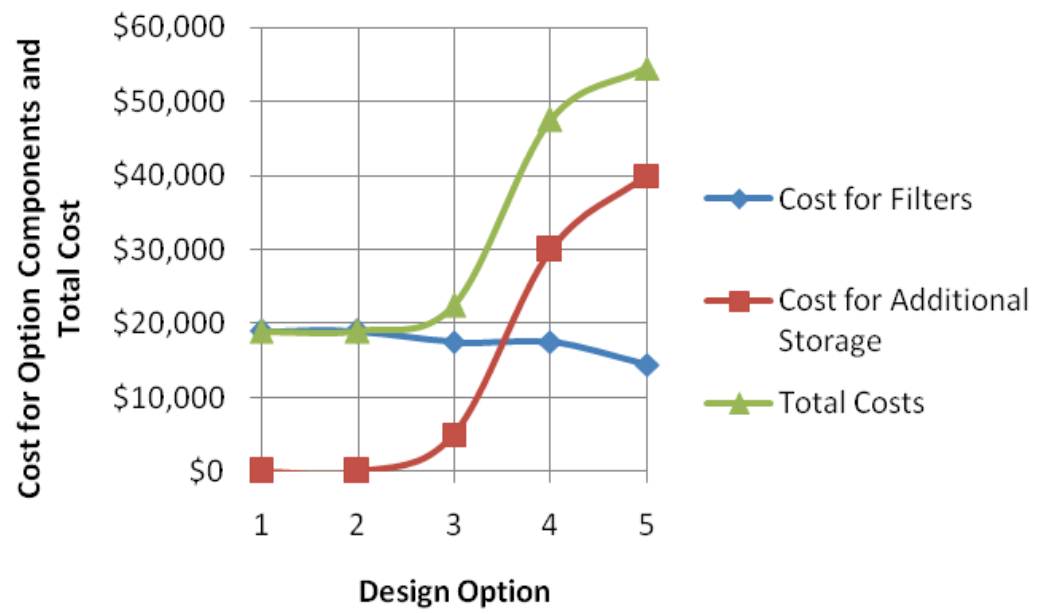

Figure 7.8 Costs for different storage-treatment options for $60 \%$ SSC load reductions.

In the third case to meet an $80 \% \mathrm{SSC}$ reduction goal, an intermediate design option is slightly more cost effective than the others, as shown in Table 7.9 and Figure 7.9. This option uses the large vault with 15 filter cartridges, plus the small vault with three more cartridges, in addition to $1240 \mathrm{ft}^{3}$ $\left(35 \mathrm{~m}^{3}\right)$ storage. The expected total cost is $\$ 62000 /$ acre $(\$ 153000 /$ ha) of impervious area to meet this TMDL discharge goal. It is possible that a larger vault that can contain all of the 18 filter cartridges would be less costly.

Table $7.980 \%$ SSC load reductions (95\% annual flow treated at $85 \%$ reductions).

\begin{tabular}{ccccccc}
\hline $\begin{array}{c}\text { Design } \\
\text { option }\end{array}$ & $\begin{array}{c}\text { Storage } \\
(\text { acre-in. })\end{array}$ & $\begin{array}{c}\text { Storage } \\
\text { volume } \\
\left(\mathrm{ft}^{3} / \text { acre }\right)\end{array}$ & $\begin{array}{c}\text { Treatment flow } \\
\text { rate needed } \\
(\mathrm{gal} / \mathrm{min} / \text { acre })\end{array}$ & $\begin{array}{c}\text { Cost for } \\
\text { filters }\end{array}$ & $\begin{array}{c}\text { Cost for } \\
\text { additional } \\
\text { storage }\end{array}$ & $\begin{array}{c}\text { Total } \\
\text { costs }\end{array}$ \\
\hline 1 & 0 & 0 & 160 & $\$ 63000$ & $\$ 0$ & $\$ 63000$ \\
2 & 0.0627 & 228 & 160 & $\$ 63000$ & $\$ 0$ & $\$ 63000$ \\
3 & 0.341 & 1240 & 130 & $\$ 57000$ & $\$ 5000$ & $\$ 62000$ \\
4 & 0.636 & 2310 & 100 & $\$ 41000$ & $\$ 30000$ & $\$ 71000$ \\
5 & 1.067 & 3880 & 53 & $\$ 33500$ & $\$ 40000$ & $\$ 73500$ \\
\hline
\end{tabular}




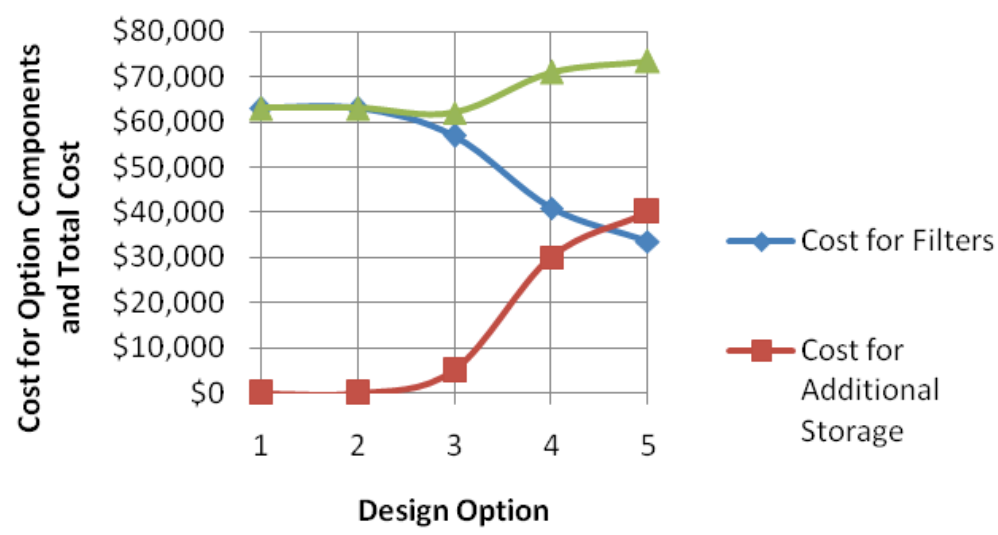

Figure 7.9 Costs for different storage-treatment options for $80 \%$ SSC load reductions.

The hypothetical filter options used in these examples may provide varying levels of treatment for different flow conditions and influent concentrations. This was not considered in these simple examples. WinSLAMM is currently being modified to incorporate stormwater media filters that will consider these additional performance attributes. Direct analyses will then be possible to evaluate different filter treatment options, with different treatment objectives (effluent quality, volume treated. or mass discharges), and to calculate life cycle costs that consider the initial construction costs (the only costs considered in the above examples), land costs, maintenance costs, and financing costs. The use of a decision analysis framework that considers other attributes is recommended for the final decisions. A detailed example of decision analysis to assist in the selection of stormwater controls is provided by Pitt and Voorhees (2007) and Alfaqih and Pitt (2009).

\subsection{Conclusions}

This chapter presents an example for conducting long term simulations of stormwater treatment filters. The results can be used to predict performance, and to prepare design curves that can assist in sizing stormwater filters for specific areas and objectives. There is a need for continuous long term simulations to evaluate and design water quality stormwater controls. The proper evaluation of urban hydrologic processes is critical, especially when calculating flows associated with small and intermediate sized rains. These 
processes, in conjunction with long term simulations, enable realistic calculations to be made. Probability distributions of modeling outcomes that relate to many receiving water objectives in urban areas can also be prepared from the results of long term water quality simulations. The use of single design storms and hydrological calculations that focus on larger events do not provide accurate or sufficient information for the rains affecting receiving water resources, and distort information pertaining to the sources of flows and pollutants.

This chapter illustrates a basic approach to the design and sizing of stormwater filters, based on treatment flow rate information. The continuous simulations produce treatment flow rate plots that can be used in evaluating different annual total flow treatment objectives. Some stormwater quality models can calculate these factors directly, while with others, it is possible to post-process high resolution flow calculation results in a spreadsheet. It is possible to determine the treatment flow rates needed to treat different fractions of the total long term flows. Combinations of storage and filtration can also be evaluated to identify the most cost effective solutions for a site.

Examples for several different treatment objectives are presented for Madison using a $5 \mathrm{y}$ rainfall record that was selected as being representative of long term conditions. These examples, using WinSLAMM, show how the treatment flow rate is dependent on treatment objectives and how, in many cases, storage can be used to reduce the overall expected costs of the treatment systems.

The methods presented in this chapter can be used by regulators to assist in the development of regulations covering treatment goals for local conditions, by manufacturers of stormwater filters in the preparation of design curves to assist in the sizing of filter units to meet these objectives, and by stormwater designers to help select alternative stormwater treatment systems. Obviously, the specific results presented in this chapter are not intended to be applied to other areas having other rain, or cost, conditions.

\section{References}

Alfaqih, L. and R.E. Pitt. 2009. "The Use of Decision Analysis and Watershed Modeling Investigate E.coli Potential Sources and Solutions in Lake Tuscaloosa Watershed, Alabama." Journal of Water Management Modeling R235-01. doi: 10.14796/JWMM.R235-01.

City of Austin (Texas). Design guidelines for water quality control basins. Environmental DCM, City of Austin Transportation and Public Services Department, 1988.

Clark, S. and R. Pitt. Stormwater Treatment at Critical Areas, Vol. 3: Evaluation of Filtration Media for Stormwater Treatment. U.S. Environmental Protection Agency, 
Water Supply and Water Resources Division, National Risk Management Research Laboratory. EPA/600/R-00/016, Cincinnati, Ohio. 442 pgs. October 1999.

Claytor, R., and T. Schueler. Design of stormwater filtering systems (DRAFT manual). Prepared for Chesapeake Bay Research Consortium in cooperation with U.S. EPA Region V, Chesapeake Bay Research Consortium. Center for Watershed Protection, Endicott, MD. 230 pages (1996).

Donigian, A.S. Jr. and R.K. Linsley. (1979). "Continuous simulation for water quality planning." Water Resources Bulletin, Vol 15, no. 1, pp 1-16.

Galli, J. Peat-sand filters: a proposed stormwater management practice for urbanized areas. Prepared for the Coordinated Anacostia Retrofit Program and Office Of Policy and Planning, D.C. Department of Public Works. (1990).

Gregory, M. and W. James. 1995. "Management of Time Series Data for Long-term Continuous Stormwater Modeling." Journal of Water Management Modeling R191-08. doi: 10.14796/JWMM.R191-08.

Pitt, R. (1986). "The incorporation of urban runoff controls in the Wisconsin Priority Watershed Program." In: Advanced Topics in Urban Runoff Research (B. Urbonas and L.A. Roesner, eds.). Engineering Foundation and ASCE, New York. pp. 290-313.

Pitt, R. (1987). Small Storm Flow and Particulate Washoff Contributions to Outfall Discharges. Ph.D. dissertation, Department of Civil and Environmental Engineering, University of Wisconsin, Madison.

Pitt, R.E. 1997. "Unique Features of the Source Loading and Management Model (SLAMM)." Journal of Water Management Modeling R200-02. doi: 10.14796/JWMM.R200-02.

Pitt, R.E. 1999. "Small Storm Hydrology and Why it is Important for the Design of Stormwater Control Practices." Journal of Water Management Modeling R204-04. doi: 10.14796/JWMM.R204-04.

Pitt, R. and J. Voorhees. (1995) "Source loading and management model (SLAMM)." Seminar Publication: National Conference on Urban Runoff Management: Enhancing Urban Watershed Management at the Local, County, and State Levels. March 30 April 2, 1993. Center for Environmental Research Information, USEPA. EPA/625/R95/003. Cincinnati. Ohio. pp. 225-243.

Pitt, R.E. and J. Voorhees. 2007. "Using Decision Analyses to Select an Urban Runoff Control Program." Journal of Water Management Modeling R227-04. doi: 10.14796/JWMM.R227-04.

Pitt, R., S.E. Clark. (2008). "Integrated stormwater management for watershed sustainability." Journal of Irrigation and Drainage Engineering. Vol. 134, no. 5, pp. 548555.

Shaver, E. (1994). Beach community adds sand filters to storm drains. Water Environment and Technology 5 (5): 18.

Urbonas, B. (1999). Design of a sand filter for stormwater quality enhancement. Water Environment Research 71 (1): 102-113. 
